\title{
Economic Analysis of Women Empowerment Through Value Addition of Jackfruit in Bengaluru Rural District
}

\author{
Deepa, M.P.M* and P.S. Srikantha Murthy \\ Department of Agricultural Economics, UAS, Bengaluru, India \\ *Corresponding author: deepapalb7004@gmail.com
}

\begin{abstract}
Present study analyzes value addition of the Jackfruit, its marketing by rural women and women empowerment in Tubagere Hobli in Bengaluru Rural district. Data was collected from all the women entrepreneurs in the study area. Six value added Jackfruit products viz, chips, jam, papad, juice, halwa and mixture are produced. A return per rupee of expenditure was highest in Jam (₹ 2.54) and lowest in Juice (₹ 1.05). They transacted an average $240 \mathrm{~kg}$ of chips, $120 \mathrm{~kg}$ of mixture, 4000 papads, 190 litres of juice, $30 \mathrm{~kg}$ of jam and $150 \mathrm{~kg}$ of halwa in 2015-2016 through direct marketing. Profit generated through value addition was higher (95\%) compared with marketing of raw fruit. Women empowerment index has shown that 50, 10 and 40 per cent of women had high, medium and low level of empowerment respectively. Thus, value addition and direct marketing have enabled them to become better empowered.

Highlights

(0 There were six value added products produced from Jackfruit in the study area.

( Jackfruit Jam was fetching higher returns as compared to other value added products of Jackfruit.

(0 Value addition activity has empowered 60 per cent of women in the study area

( Through the value addition and marketing of Jackfruit products women in the study area were able to save an average of ₹ 20,000 to ₹ 25,000. This helped them to purchase some valuable assets like gold.
\end{abstract}

Keywords: Jackfruit, marketing, profit, value addition and women empowerment

Artocarpus heterophyllus, commonly known as jackfruit, is evergreen latex producing tree species which belongs to the family Moraceae. Archaeological findings indicate that jackfruit was cultivated in India 3000 to 6000 years ago and it has played a significant role in Indian agriculture from centuries. It is an economically important Artocarpus species which is found to be distributed in southern states like Kerala, Tamil Nadu, Karnataka, Goa, coastal Maharashtra and other states like, Assam, Bihar, Tripura, Uttar Pradesh and foothills of Himalayas in India. Jack fruit is a rich source of several nutrients. It is equivalent to Avocado and olive in terms of healthier mix of nutrients in human dietary needs, almost having the exact nutrient equivalents of mother's milk. It's seeds are rich in proteins and can be eaten as a nutritious nuts. Fruit contains a chemical called "Jacalin" useful in preventing colon cancer, AIDS etc. Perishable nature of the fruit has created a considerable gap between its production and availability, resulting in 20-30 per cent postharvest losses. This can be overcome by increasing shelf life of the fruit through value addition into several products like squash, jam, candy, halwa, chips, papad, mixture etc. It provides tremendous opportunity for raising income of the farmers even in off season. Since rural women play a vital role in farm activities and household management they can start Value added product based entrepreneurship with minimum initial investment. Entrepreneurial activities provide a wider scope for women empowerment in the rural areas, which is a precondition for poverty elimination and upholding human rights. The present study attempted to adress value addition of the jackfruit and its marketing through rural women 
YD Deepa and Murthy

and extent of women empowerment through these activities.

\section{Objectives}

1. To estimate the value addition in Jackfruit and marketing of value added products.

2. To assess the extent of women empowerment generated by value addition in Jackfruit.

\section{MATERIALS AND METHODS}

\section{Data}

Based on the area and production of Jackfruit Tubagere Hobli of Doddaballapura taluk of Bengaluru Rural district was purposively selected for the present study. To elicit the required data regarding value addition processes like procurement, sorting, grading, product preparation, packing, storage, transportation, a total of 10 women enter pruners who were also involved in marketing of the products were selected. The data was collected with the help of pretested schedules during the agricultural year 2015-2016.

\section{Analytical tools}

The analytical tools employed in the present study are elaborated under the following headings.

\section{Costs and returns of Jackfruit value added products}

About six value added products from jackfruit are being produced by the women processors in the study area. Costs and returns for each of the value added product was worked out. Computation included:

Cost of production: The expenses incurred on inputs and input services in producing a unit quantity of output. In the study the amount spent on various inputs including labour were calculated.

Gross returns $=$ Price $\times$ Total output sold

Net returns $=$ Gross returns - Total cost

Returns per rupee of expenditure $=$

$\frac{\text { Gross returns }}{\text { Total cost of production }}$

\section{Women Empowerment Index}

In order to study the empowerment of women involved in jackfruit value addition in the study area, a women empowerment index was developed. For this, variables such as, education of the women, savings made, control over the family expenditure, family decision making, their participation in the social organizations, their decision to join as member of Jackfruit Growers' Association (JGA), category to which they belong and family type were considered. The scores assigned to these variables are represented in the Table 2.

The variables were given weights by dividing actual score of each variable with maximum score of the same variable (Sakamma, 2013). Hence, the weight assigned was found to be more precise as it varied across each respondent and variable. Further this weight was multiplied with the values of each variable and summated. The empowerment index was worked out by dividing the index of each respondent with highest index.

Women Empowerment index $=\frac{\sum_{j=1}^{P}\left[\left(A_{i j} / H\right) A_{i j}\right]}{\max \left[\Sigma\left(A_{i j} / H\right) A_{i j}\right]}$

Where,

$i=$ number of respondents

$A_{i j}=$ Actual value/score of $\mathrm{i}^{\text {th }}$ respondent and $\mathrm{j}^{\text {th }}$ variable

$H=\left[\max \left(A_{i j}\right)\right]=$ Maximum Value/ score of $\mathrm{i}^{\text {th }}$ respondent and $\mathrm{j}^{\text {th }}$ variable

$p=$ Number of variables

Mean and Standard deviation were worked out by taking final empowerment indices of each respondent. The individuals who had the index greater than mean plus half standard deviation were categorized as having high level of empowerment, those who had an index less than mean minus half standard deviation as low level of empowerment and those who had an index in between these two ranges were categorized as having medium level of empowerment. Thus women were categorized as having high, medium and low level of empowerment index.

\section{RESULTS AND DISCUSSION}

Input use pattern of six value added products of Jackfruit were analysed and given in the Table 1 . Jackfruit, cooking oil, chilli powder, flattened rice, 
Economic Analysis of Women Empowerment Through Value Addition of Jackfruit... $\mathcal{C}$

Table 1: Input use pattern in Jackfruit value addition

\begin{tabular}{|c|c|c|c|c|c|c|c|c|c|c|c|c|c|}
\hline \multirow{2}{*}{$\begin{array}{l}\text { Sl. } \\
\text { No. }\end{array}$} & \multirow[t]{2}{*}{ Particulars } & \multicolumn{2}{|c|}{$\begin{array}{c}\text { Chips } \\
\text { (One Kg) }\end{array}$} & \multicolumn{2}{|c|}{$\begin{array}{l}\text { Mixture } \\
\text { (One Kg) }\end{array}$} & \multicolumn{2}{|c|}{$\begin{array}{c}100 \\
\text { papads }\end{array}$} & \multicolumn{2}{|c|}{$\begin{array}{c}\text { Halwa } \\
\text { (One Kg) }\end{array}$} & \multicolumn{2}{|c|}{$\begin{array}{c}\text { Juice } \\
\text { (One litre) }\end{array}$} & \multicolumn{2}{|c|}{$\begin{array}{c}\text { Jam } \\
\text { (One kg) }\end{array}$} \\
\hline & & $\mathbf{Q}$ & TC (₹) & $\mathbf{Q}$ & TC (₹) & $\mathbf{Q}$ & TC (₹) & $\mathbf{Q}$ & TC (₹) & $\mathbf{Q}$ & TC (₹) & $\mathbf{Q}$ & TC (₹) \\
\hline \multicolumn{14}{|c|}{ Raw materials } \\
\hline 1 & Jackfruit (kg) & 4.5 & 45 & 0.3 & 3 & 1 & 10 & 0.5 & 5 & 0.25 & 2.5 & 0.75 & 7.5 \\
\hline 2 & Cooking Oil (kg) & 0.5 & 40 & 0.25 & 20 & - & - & - & - & - & - & - & - \\
\hline 3 & Chilli powder (g) & 45 & 12 & 50 & 12 & - & - & - & - & - & - & - & - \\
\hline 4 & Salt (g) & 45 & 0.5 & 50 & 0.5 & 50 & 2.5 & - & - & - & - & - & - \\
\hline 5 & Flattened rice $(\mathrm{Kg})$ & - & - & 0.75 & 22 & - & - & - & - & - & - & - & - \\
\hline 6 & Peanuts (g) & - & - & 200 & 15 & - & - & - & - & - & - & - & - \\
\hline 7 & Chana dal (g) & - & - & 200 & 15 & - & - & - & - & - & - & - & - \\
\hline 8 & Bird eye pepper (g) & - & - & - & - & 15 & 25 & - & - & - & - & - & - \\
\hline 9 & Pepper powder ( g) & - & - & - & - & 2 & 3 & - & - & - & - & - & - \\
\hline 10 & Ghee (litre) & - & - & - & - & - & - & 0.38 & 125 & - & - & - & - \\
\hline 11 & Sugar (kg) & - & - & - & - & - & - & 0.75 & 33 & 0.25 & 22 & 0.25 & 14 \\
\hline 12 & Preservative (g) & - & - & - & - & - & - & - & - & 0.25 & 0.5 & 0.25 & 0.5 \\
\hline 13 & $\begin{array}{l}\text { Packing material } \\
\text { (number) }\end{array}$ & 10 & 2.5 & 10 & 2.5 & 10 & 2.5 & 10 & 50 & 2 & 20 & 10 & 50 \\
\hline 14 & $\begin{array}{l}\text { Labelling material } \\
\text { (number) }\end{array}$ & 10 & 12 & 10 & 12 & 10 & 12 & 10 & 12 & 2 & 5 & 10 & 12 \\
\hline 15 & Cost of transportation (₹) & - & 6 & 0 & 6 & 0 & 0.35 & 0 & 9 & 0 & 7 & - & 28 \\
\hline 16 & Miscellaneous & - & 10 & - & 10 & -- & 8 & - & 8 & - & 6 & - & 10 \\
\hline \multirow[t]{2}{*}{17} & Family labour (number) & 2 & 50 & 2 & 50 & 3 & 75 & 1 & 25 & 1 & 25 & 1 & 25 \\
\hline & Total & & 178 & & 168 & & 138 & & 267 & & 88.6 & & 147 \\
\hline
\end{tabular}

Q : Quantity TC : Total Cost.

peanuts, channa dal, bird eye pepper and pepper powder are the inputs used in production of chips, mixture and papads. Sugar, ghee and preservatives are used in the production of halwa, juice and jam. They use $0.25 \mathrm{~g}$ of sodium benzoate as preservative in production of one litre of juice and one $\mathrm{kg}$ of Jam.

Production of and returns from the Jackfruit value added products are given in the Table 2 . According to which, average quantity of chips produced per women entrepreneur in the study area was $24 \mathrm{~kg}$ with the total cost of production of ₹ 4,566.76. Gross returns realised was $₹ 7200$ and net return was $₹$ 2633.34. Average quantity of mixture produced per women entrepreneur in the study area was 12 $\mathrm{kg}$ with the total cost of production of ₹ 2157.12. Gross returns realised was ₹ 2400 and net return was ₹ 242.88. Average quantity of papads produced per women entrepreneurs in the study area was 400, with the total cost of production of ₹ 615.25. Gross returns realised was $₹ 1200$ and net return was $₹ 584.75$. Average quantity of halwa produced per women entrepreneur in the study area was $15 \mathrm{~kg}$, with the total cost of production of ₹ 4269.3. Gross returns realised was ₹ 6000 and net return was $₹$ 1730.7. Average quantity of juice produced per women entrepreneur in the study area was 19 litres. Total cost of production of Juice was ₹ 1802.95. Gross returns realised was ₹ 1900 and net return was ₹ 97.05. Average quantity of jam produced per women entrepreneur in the study area was $5 \mathrm{~kg}$ with the total cost of production of ₹ 786.45. Gross returns realised was ₹ 2000. The net return was ₹ 1213.55 .

Product wise value addition estimation in Jackfruit has been presented in the Table 3. Among the six value added products cost of production of Halwa was higher because of the use of ghee and sugar in considerable quantity to enhance the quality and taste of it. It was sold at ₹ 400 per $\mathrm{kg}$ by realising a profit of ₹ 114.31. Next to Halwa, Chips production had a higher cost of ₹ 190.48 per $\mathrm{kg}$ and was sold at a price of ₹ 300 realising a profit of ₹ 109.52. Cost of Jackfruit and labour were higher here as producing 
Table 2: Returns from the Jackfruit value added products

\begin{tabular}{|c|c|c|c|c|c|c|c|c|c|c|c|c|}
\hline \multirow{2}{*}{$\begin{array}{c}\text { Products } \\
\text { Production }\end{array}$} & \multicolumn{2}{|c|}{ Chips } & \multicolumn{2}{|c|}{ Mixture } & \multicolumn{2}{|c|}{ Papads } & \multicolumn{2}{|c|}{ Halwa } & \multicolumn{2}{|c|}{ Juice } & \multicolumn{2}{|c|}{ Jam } \\
\hline & $\begin{array}{l}24 \\
\mathrm{~kg}\end{array}$ & $\begin{array}{c}\text { One } \\
\text { kg }\end{array}$ & $\begin{array}{l}12 \\
\mathrm{~kg}\end{array}$ & $\begin{array}{c}\text { One } \\
\text { kg }\end{array}$ & $\begin{array}{c}400 \\
\text { Papads }\end{array}$ & $\begin{array}{c}100 \\
\text { Papads }\end{array}$ & $\begin{array}{l}15 \\
\mathrm{~kg}\end{array}$ & $\begin{array}{c}\text { One } \\
\text { kg }\end{array}$ & $\begin{array}{c}19 \\
\text { litre }\end{array}$ & $\begin{array}{l}\text { One } \\
\text { litre }\end{array}$ & $\begin{array}{c}5 \\
\mathrm{~kg}\end{array}$ & $\begin{array}{c}\text { One } \\
\text { kg }\end{array}$ \\
\hline Price(/kg) & 300 & 300 & 200 & 200 & 300 & 300 & 400 & 400 & 100 & 100 & 400 & 400 \\
\hline \multicolumn{13}{|l|}{ Cost } \\
\hline Cost of production (₹) & 4268 & 178 & 2016 & 168 & 575 & 138 & 3990 & 267 & 1685 & 88.68 & 735 & 147 \\
\hline $\begin{array}{c}\text { Interest on the } \\
\text { working capital @ } 7 \\
\text { per cent }\end{array}$ & 298.76 & 12.48 & 141.12 & 12.18 & 40.25 & 9.66 & 279.3 & 18.69 & 117.95 & 6.21 & 51.45 & 10.29 \\
\hline $\begin{array}{c}\text { Total cost of } \\
\text { production }(₹)\end{array}$ & 4566.76 & 190.48 & 2157.12 & 180.18 & 615.25 & 147.66 & 4269.3 & 285.69 & 1802.95 & 94.89 & 786.45 & 157.29 \\
\hline \multicolumn{13}{|l|}{ Returns } \\
\hline Gross returns (₹) & 7200 & 300 & 2400 & 200 & 1200 & 300 & 6000 & 400 & 1900 & 100 & 2000 & 400 \\
\hline Net returns (₹) & 2633.2 & 109.52 & 242.88 & 13.83 & 584.75 & 152.34 & 1730.7 & 114.31 & 97.05 & 5.11 & 1213.55 & 242.71 \\
\hline
\end{tabular}

Table 3: Product wise value addition estimation in Jackfruit

\begin{tabular}{ccccccc}
\hline S1. No & Products & $\begin{array}{c}\text { Quantity of value } \\
\text { added products }\end{array}$ & $\begin{array}{c}\text { Cost of production } \\
\text { (₹) }\end{array}$ & Returns (₹) & Profit (₹) & $\begin{array}{c}\text { Returns per rupee of } \\
\text { expenditure (₹) }\end{array}$ \\
\hline 1 & Chips (kg) & 1 & 190.48 & 300 & 109.52 & 1.57 \\
2 & Mixture (kg) & 1 & 180.18 & 200 & 19.82 & 1.11 \\
3 & Papad (number) & 100 & 147.60 & 300 & 152.40 & 2.03 \\
4 & Jam (kg) & 1 & 157.29 & 400 & 242.71 & 2.54 \\
5 & Juice (litre) & 1 & 94.89 & 100 & 5.11 & 1.05 \\
6 & Halwa (kg) & 1 & 285.69 & 400 & 114.31 & 1.40 \\
\hline
\end{tabular}

each $\mathrm{kg}$ of chips needed $5 \mathrm{~kg}$ of unripe fruit which has to be sliced to a proper size.

Return per rupee of expenditure was the highest in case of Jam at ₹ 2.54. The reason was low cost of production as compared to that for other products, higher demand / higher consumer preference which led to the high price for the Jam. Returns per rupee of expenditure for papad was ₹ 2.04, for chips ₹ 1.57 , for halwa ₹ 1.40 , for mixture ₹ 1.11 . It was the lowest in Juice at ₹ 1.05 , because of the addition of the preservatives that gives some sour taste. Hence, juice had less consumer preference as compared to other products and had a margin of only ₹ 5.11 per litre.

Farmers in the study area earned an average profit of ₹ 111.5 per fruit (of 9-10 kg). While, the women processors prepared two $\mathrm{kg}$ of chips from each fruit and realized a profit of ₹ 219. That is 96.4 per cent higher profit per fruit. They prepared $1.5 \mathrm{~kg}$ of Jam from each fruit and realized a profit of ₹ 364 that is 226.51 per cent higher profit per fruit. Similarly value addition in the form of Halwa and papad also generated higher profits. This shows the extent of value addition to the Jackfruit through processing and gives a proof for higher returns from value addition. The results are in conformity with the ones obtained by Kusuma et al. (2013), which showed the net return realized from foxtail millet cultivation was ₹ 5582.79 per hectare where as the net returns realised by producing Papad and Tambittu from foxtail millit was ₹ 4880 and ₹ 5960 respectively and returns per rupee of expenditure was found to be higher in value added products at ₹ 1.70 in Papad and at $₹ 1.73$ in Tambittu.

\section{Marketing of Value added Jack products}

\section{Marketing Channel}

Producers cum Processors $\rightarrow$ Consumers

Women entrepreneurs who have their own jackfruit trees and involved in processing are called here as producers cum processors and they followed direct marketing of their value added Jackfruit products. They produce six value added jackfruit 
Economic Analysis of Women Empowerment Through Value Addition of Jackfruit... $\mathcal{C}$

Table 4: Scores assigned to the variables taken to work out the empowerment index

\begin{tabular}{|c|c|c|c|c|c|c|c|}
\hline \multicolumn{8}{|c|}{ Scores } \\
\hline S1. No. & Particulars & 0 & 1 & 2 & 3 & 4 & 5 \\
\hline 1 & Education & Illiterate & Primary education & $\begin{array}{l}\text { Middle school } \\
\text { education }\end{array}$ & $\begin{array}{l}\text { High school } \\
\text { education }\end{array}$ & PUC & $\begin{array}{l}\text { Degree and } \\
\text { above }\end{array}$ \\
\hline 2 & Savings & No savings & $\begin{array}{l}\text { Savings between } \\
₹ 1000 \text { to ₹ } 10000\end{array}$ & $\begin{array}{l}\text { Savings between } \\
\text { ₹ } 11000 \text { to ₹ } 20000\end{array}$ & $\begin{array}{l}\text { Savings } \\
\text { between } \\
\text { ₹ } 21000 \text { and } \\
\text { above }\end{array}$ & - & - \\
\hline 3 & $\begin{array}{l}\text { Control over } \\
\text { the family } \\
\text { expenditure }\end{array}$ & $\begin{array}{l}\text { No access } \\
\text { to family } \\
\text { expenditure by } \\
\text { women }\end{array}$ & $\begin{array}{l}\text { Access to family } \\
\text { expenditure along } \\
\text { with their husband }\end{array}$ & Self-access & - & - & - \\
\hline 4 & $\begin{array}{l}\text { Family decision- } \\
\text { making }\end{array}$ & $\begin{array}{l}\text { Women don't } \\
\text { have any hold on } \\
\text { family decisions' }\end{array}$ & $\begin{array}{l}\text { Women have say } \\
\text { in family decision } \\
\text { making along with } \\
\text { the husband }\end{array}$ & $\begin{array}{l}\text { Women have } \\
\text { complete hold on } \\
\text { the family decision } \\
\text { making }\end{array}$ & - & - & - \\
\hline 5 & $\begin{array}{l}\text { Participation } \\
\text { in the social } \\
\text { organization }\end{array}$ & $\begin{array}{l}\text { Not a member of } \\
\text { any organization }\end{array}$ & $\begin{array}{l}\text { Member of any social } \\
\text { organization'. }\end{array}$ & - & - & - & - \\
\hline 6 & $\begin{array}{l}\text { Decision to join } \\
\text { as member of } \\
\text { Jackfruit Growers' } \\
\text { Association (JGA) }\end{array}$ & $\begin{array}{l}\text { No decision taken } \\
\text { by women }\end{array}$ & $\begin{array}{l}\text { Decision taken by } \\
\text { women along with } \\
\text { the husband }\end{array}$ & Self-decision & - & - & - \\
\hline 7 & Family type & Nuclear family & Joint family. & - & - & - & - \\
\hline 8 & Category & - & $\begin{array}{l}\text { Women belonging to } \\
\text { SC/ST category }\end{array}$ & $\begin{array}{l}\text { Women belonging } \\
\text { to other categories }\end{array}$ & - & - & - \\
\hline
\end{tabular}

products like chips, mixture, papad, jam, juice and halwa. Total quantity of these value added products transacted in 2015-2016 included $240 \mathrm{~kg}$ (average of $24 \mathrm{~kg}$ ) of chips, $120 \mathrm{~kg}$ of mixture (average $12 \mathrm{~kg}$ ), 4000 papads (10 papads in each packet, average of 400 papads), 190 litres of juice (average of 19 litres), $30 \mathrm{~kg}$ of jam (average of $3 \mathrm{~kg}$ ) and $150 \mathrm{~kg}$ of halwa (average of $15 \mathrm{~kg}$ ).

\section{Women empowerment through Jackfruit value addition}

The respondents were post-stratified into high, medium and low empowerment categories based on empowerment index constructed by taking into account set of socio-economic variables like, education, family decision making, decision to join as member of JGA and other cooperatives, which are presented in Table 4 . Results of empowerment index are given in Table 5. Among the Women entrepreneurs, five (50 per cent) had high level of empowerment. Because they had higher education as compared to other members which helped them to convince their family members regarding their participation in meetings, melas (sales) held in far places like Lalbagh (Bengaluru), Mangalure. The women belonging to high empowerment group were able to save more than ₹ 25,000 per annum. One (10 per cent) Woman entrepreneur had medium level of empowerment.

Table 5: Classification of women entrepreneurs based on empowerment index

\begin{tabular}{ccc}
\hline Level of & \multicolumn{2}{c}{ Processors (N=10) } \\
\cline { 2 - 3 } Empowerment & Number & Percentage \\
\hline High & 5 & 50 \\
Medium & 1 & 10 \\
Low & 4 & 40 \\
\hline
\end{tabular}

As compared to high empowered women she had less education, family decisions were taken along with the husbands and had the saving amount between ₹ 11,000 to 20,000 and four (40 per cent) of the women entrepreneurs had low level of empowerment. They had only primary education 
CD Deepa and Murthy

and most of the time the family decisions were taken by the men in their family and they were able to save an amount of ₹ 1,000 to 10,000 per year.

They had participated in training programmes and association meetings held in Hadonahalli Krishi Vigyan Kendra (KVK). Which helped them to acquire skills, self-confidence to earn income to their family by making value added products from Jackfruit. They got an opportunity to mingle and work with other people. Most of the women expressed that they were happy with their earnings and have a plan to produce various products.

\section{CONCLUSION}

It is evident from the study that value addition in Jackfruit increases the income to the extent of more than 95 per cent as compared to selling of the raw fruit. It also paves way for direct marketing, development of communication skills and self confidence among women entrepreneurs in the study area. It has helped 50 per cent of the rural women to save more than ₹ 25,000 per annum. Thus encouraging rural women to take up value addition activities is an important component of increasing profitability, house hold savings and women empowerment in the rural area.

\section{ACKNOWLEDGMENTS}

The study was carried out with help of Junior Research Fellowship (JRF) provided by Indian Council of Agricultural Reearch (ICAR) New Delhi for the period of two years from 2015-2017.

\section{REFERENCES}

Ajit, B. 2014. Women empowerment through self help groupsa case study of Barhampur development blocks in Nagaon district of Assam. IOSR Journal of Economics and Finance, 4: 56-62.

Bharathamma, G.U., Angadi, J.G., Hirevenkanagoudar, L.V. and Natikar, K.V. 2006. Empowerment of rural women through income generating activities. Karnataka J. Agric. Sci., 19: 600-602.

Chandrima, C. 2015. Women empowerment: An indicator based inter- country comparison. International Journal of Commerce, Business and Management, 4: 968-971.

Dodamani, M.T. and Kunnal, L.B. 2007. Value-addition to organically produced naturally-coloured cotton under contract farming. Agricultural Economics Research Review, 20: 521-528.

Khan, T.M. and Maan, A.A. 2008. Socio-cultural milieu of women's empowerment in district Faisalabad. Pakistan Journal of Agriculture Science, 45: 78-90.

Kiran, Dipak, D., Gupta, B.K., Pandey, D.K. and Upadhaya, A.D. 2012. Empowerment of rural women in agriculture: a socio-psychological analysis. Studies on Home and Community Science, 6: 139-144.

Kusuma, D.K., Jayashree, A.H. and Kumara, B.R. 2013. An economic analysis of production and value addition in foxtail millet in Bellary district of Karnataka. Int. Res. J of Agri. Economics and Statistic, 4: 68-72.

Michael, K.A. and John, K.M. 2014. A comparative analysis of the profitability of pineapple-mango blend and pineapple fruit juice processing in Ghana. Applied Studies in Agribusiness and Commerce, 8: 33-42.

Sakamma, S. and Umesh, K.B. 2016. Construction of empowerment index: A case of farm women. Int. J of Tropical Agri., 34: 1141-1148.

Thippanna, K.S., Shwetha, M.K., Balachandra, K.N. and Srinivas, N. 2016. Economics of processing and marketing of different value added products of grapes in north Karnataka. Int. J. of Commerce and Business Management, 9: 169-174. 